\title{
Hypericum scruglii Bacch., Brullo \& Salmeri, a Potential Natural Remedy for Fibromyalgia: A Narrative Review
}

\author{
Goce Kalcev 1,*(i) , Giorgia Testa ${ }^{1}$ (i), Maria Manconi ${ }^{2}$ (i) , Gianluigi Bacchetta ${ }^{2}$ (iD), \\ Alessandra Scano $^{3}$ (i) , Germano Orrù $^{3}$ (i) , Maria Cristina Deidda ${ }^{4}$ (i) , Gabriele Finco $^{5}$ (i), \\ Mauro Giovanni Carta 5 (i)
}

1 International PhD in Innovation Sciences and Technologies, University of Cagliari, Via Ospedale, 46, 09124, Cagliari, Italy; gocekalcev@yahoo.com (G.K.); testa_giorgia@yahoo.it (G.T.);

2 Department of Life and Environmental Sciences, University of Cagliari, via Ospedale, 72, 09124, Cagliari, Italy; manconi@unica.it (M.M.); bacchet@unica.it (G.B.);

3 Department of Surgical Sciences, University of Cagliari, Via Ospedale, 46, 09124, Cagliari, Italy; alessandrascano@libero.it (A.S.); gerorru@gmail.com (G.O.);

4 University Hospital of Cagliari, Via Ospedale, 46, 09124, Cagliari, Italy; mc.deidda@ jaserv.com (M.C.D.);

5 Department of Public Health, Clinical and Molecular Medicine, University of Cagliari, Via Ospedale, 46, 09124, Cagliari, Italy; gabriele.finco@unica.it (G.F.); mgcarta@tiscali.it (M.G.C.);

* Correspondence: gocekalcev@yahoo.com;

Scopus Author ID 57218516043

Received: 2.09.2020; Revised: 20.09.2020; Accepted: 21.09.2020; Published: 23.09.2020

\begin{abstract}
Fibromyalgia (FM) is a disorder of central pain processing marked by widespread chronic pain together with fatigue, sleep disturbances, cognitive dysfunction, and depressive episodes. Tested treatments have expressed limited efficacy. Oxidative stress plays a role in the pathology of FM, while multiple neurotransmitters are involved in this syndrome. Antidepressants are used as conventional treatment, especially those with double action on serotonin and norepinephrine that leads to an increased risk of a manic switch. It should be noted that fibromyalgia is high-frequency comorbidity in bipolar disorder. This narrative review, given the limited literature, consisted of animal and in vitro studies, which aims to highlight the positive aspects of Hypericum scruglii as a potential remedy against FM. Many in vitro and clinical studies confirm the Hypericum genus as a natural antidepressant resource. The use of Hypericum derivatives in various acute and chronic diseases has been known for a long time. It is reported that the phloroglucinol derivatives from Hypericum longistylum improve and accelerate the differentiation of neural progenitor cells. The advantage of Hypericum scruglii is that it owns greater antioxidant potential than other species of the Hypericum genus. Suggestions for improving the oral bioavailability of very poor water-soluble molecules of hypericum extracts are also described in this paper.
\end{abstract}

Keywords: fibromyalgia; Hypericum scruglii; Hypericaceae; antidepressive; manic switch.

(C) 2020 by the authors. This article is an open-access article distributed under the terms and conditions of the Creative Commons Attribution (CC BY) license (https://creativecommons.org/licenses/by/4.0/).

\section{Introduction}

Fibromyalgia (FM) is a syndrome characterized by diffuse pain as a crucial symptom with various other symptoms such as anxiety, fatigue, mood disorder, sleep disturbances, cognitive decline, and episodes of depression [1]. The prevalence of this syndrome is $3 \%$ in the societies of western countries, with a predisposition for more frequent occurrence in women [2]. Fibromyalgia is often associated with irritable bowel syndrome (IBS), chronic fatigue syndrome, temporomandibular disorder (TMD), irritable bladder syndrome, or interstitial cystitis, multiple sclerosis (MS) [3]. Patients with fibromyalgia and associated conditions 
experience hyperalgesia (intense pain responses to normally painful stimuli) and/or allodynia (responses accompanied by pain normally nonpainful stimuli) [4, 5]. All of this points to the fact that these patients have problems with sensory processing of pain. Better approaches in understanding fibromyalgia and associated conditions took place after researchers realized that these conditions don't seem to be caused by inflammation or peripheral damage and instead of that begun to analyze the central neural mechanisms, as prototypical central pain syndrome [4].

The severity of this disease, which drastically changes the quality of life of patients, puts it in a group of important public health issues. A limitation in treatments for FM has been shown so far [2]. However, oxidative stress plays a key role in the pathophysiology of FM. In addition, the total antioxidant capacity and plasma levels of antioxidant enzymes are reduced in patients with FM [6]. Contrary, the amount of hydrogen peroxide $\left(\mathrm{H}_{2} \mathrm{O}_{2}\right)$ as one of the free oxidative radicals is increased in neutrophils in these patients [7]. Otherwise, increasing evidence suggests that there are a number of modifications in the neurotransmitter systems in fibromyalgia.

As is already known, the key symptom and the main diagnostic criteria for this disease is extensive pain. The central neurotransmitters serotonin and noradrenaline are involved in endogenous pain-inhibitory transmission pathways [8,63]. They are related to circadian rhythms [9]. Serotonin via the 5hydroxytryptamine (5HT3) receptor plays a key role in descending pain facilitation [10]. This neurotransmitter is of great importance because it mediates deep sleep [11]. In general, sleeping is negatively linked to pain in FM patients. These patients experience poor quality of sleep (daytime sleepiness, sleep disturbances, daytime disturbances) along with pain [56]. Moreover, deficiency of serotonin is associated with major depression [12]. As well, studies with proton magnetic resonance spectroscopy have shown that glutamate as a neurotransmitter is increased in the amygdala, insula, cingulate cortex during pain processing [13]. Supporting the fact that the hyperactive glutamate system leads to increased pain sensitivity and may be the cause of other fibromyalgia symptoms, increased glutamate levels in the insular cortex are associated with low-pressure pain thresholds [14].

A role may also be played by the gamma-aminobutyric acid (GABA) neurotransmitter, which is the principal inhibitory neurotransmitter in the central nervous system. Certain pharmacological studies have shown some efficacy of GABAergic agents for pain, fatigue, and sleep, suggesting that this neurotransmitter may be involved in the pathophysiology of fibromyalgia [15]. Several studies have shown that dietary elements improve the functional and psychological status of FM and, at the same time, protect the body from oxidative stress due to establishing a balance between glutamate and GABA [16]. It is well known that fibromyalgia is associated with depressive, bipolar and anxiety disorders. Data on the increased incidence of panic and generalized anxiety disorders in patients with FM are an indirect indicator of the risk of bipolar disorder (BD). Furthermore, patients with bipolar disorder are known to have an increased risk of anxiety disorders [17, 64]. Due to the association of FM with bipolar disorder, the use of antidepressants with a double-action in strengthening serotonin and norepinephrine can significantly increase the risk of a manic switch. Obviously, this is why antidepressants do not change long-term outcome remission indicators [18, 57].

What's more, fibromyalgia is intimately linked with PTSD, and, together, they cause a catastrophic impairment of the quality of life [58-61]. The point is that antidepressants are effective because they not only act on depressive episodes but also on the pain circuits. But on the other hand, the risk of the manic switch is high (due to the association with bipolar 
disorder). This probably explains the lack of long-term efficacy [65-69]. The aim of this review is the necessity to explore the possibility of other remedies for FM.

\section{Materials and Methods}

This narrative review, based on in vitro and in vivo animal studies, aims to evaluate the efficacy of Hypericum scruglii Bacch., Brullo \& Salmeri, an endemic plant found in Sardinia, Italy, on fibromyalgia.

\section{Results and Discussion}

\subsection{Hypericum in depressive disorders.}

Hypericum L. is a genus of flowering plants that belong in the family Hypericaceae. Hypericum perforatum L. (better known as St John's wort) is an herbaceous perennial plant frequently found in Asia and Europe. It's a preferred herbal remedy recommended by traditional Chinese medical (TCM) practitioners for the treatment of depression [19]. This is evidenced by the fact that it is prescribed to patients and licensed in a number of European countries [20]. The active ingredients of Hypericum perforatum are hypericin and hyperforin. Hyperforin is considered to be a major component of this plant in the fight against depressive disorders, as it inhibits the reuptake of the neurotransmitters serotonin, noradrenaline, and dopamine. In the way, it is observed that it is similar to the effect of tricyclic antidepressants and selective serotonin reuptake inhibitors, but with milder and to lesser extent side effects and with significantly lower discontinuation/dropout due to side effects [21, 22]. The main effects of Hyperforin observed in vitro (at concentrations of 0.1-1 $\mu \mathrm{M}$ ) are non-selective inhibition of uptake of GABA, glutamate, and choline. It is important to note that this active ingredient inhibits serotonin reuptake in experimental conditions in a dose-dependent procedure [23]. In addition, the findings of a meta-analysis only confirmed the fact that St John's wort extract is more effective and safer than standard SSRIs. One of the disadvantages of this extract is the occurrence of pharmacokinetic interactions during concomitant use of drugs [21]. This is due to the fact that the hypericin component is an activator of the hepatic metabolic enzyme CYP1A2, while the hyperforin component is an activator of CYP3A4. This is significant because these two enzymes are involved in the metabolism of numerous drugs. It should be noted the danger of developing life-threatening serotonin syndrome as a result of an excess of the central serotonin while taking other drugs, e.g., SSRIs [24]. However, if this extract is used in low doses as a dietary supplement, then there is a small risk of drug interactions [21]. Moreover, ethanol extracts of $H$. perforatum contain phenolic components such as flavonoids and phenolic acids that have a strong antioxidant function [25]. Recently, a Chinese in vitro study published results about key phloroglucinol derivatives of Hypericum longistylum Oliv., which had a positive effect on neuronal differentiation and serotonergic neuron production. Association of the impact of components of $H$. longistylum and neurogenesis is thought to be the reason for improved behavior in mice under stressful conditions, and a reduction in depressive symptoms simultaneously [26].

\subsection{Hypericum genus as a possible tool in the treatment of fibromyalgia.}

Its antidepressant properties, along with its potential effect on the serotonergic system, which is a major driver of pain cycles, make Hypericum genus the type of possible treatment 
for fibromyalgia. The effectiveness and safety of $H$. perforatum in the treatment of depressive disorders have been extensively studied in clinical trials with various designs (open trials or randomized, controlled trials); diverse populations (adolescents, adults, or the elderly); and different control groups (antidepressant or placebo). Moreover, contrary to all other antidepressants, St. John's wort also has a clear inhibitory impact on the synaptosomal uptake of the neurotransmitters L-glutamate and (GABA). Understandable is the fact that despite St. John's wort share some mechanisms of action with conventional antidepressant drugs, it is possible to perform via novel mechanisms of action, which needs further investigation [21].

On behalf of its possible effects on the serotonergic system, which in turn plays a role in pain circuits, as well as its properties as an antidepressant and supremely low profile of side effects, the Hypericum genus is gaining importance as a potential plant genus for the treatment of fibromyalgia [21]. However, have been reported cases of induction of manic state, especially when plants of this genus have been used as an antidepressant. There is interesting evidence from a review in which mania appears as the main consequence of using various herbal plants, including $H$. perforatum.

This plant shows a forceful association with manic switch. It is described that patients, due to depression and relief of post-traumatic stress symptoms, decided for therapy with Hypericum perforatum. Significantly, symptoms of mania and hypomania occurred in fourteen patients, out of thirty-five patients. It has to be considered the fact that three patients from this group are with a history of bipolar disorder [28]. The explanation for this phenomenon lies in the knowledge that these patients have a greater predisposition to bipolar disorder, fluctuation of the already confirmed affective disorder, antidepressant, and plant-induced mania [29]. The mechanism by which this plant works for mania inclination is not yet sufficiently clarified. The enigma is growing as it becomes difficult to distinguish between spontaneous manic episodes and those caused by antidepressants [30]. Other interesting related cases have been described in the literature.

There is a patient who underwent a bilateral orchidectomy for cryptorchidism. The same patient develops depression. Firstly, he was treated with testosterone and a conventional selective serotonin reuptake inhibitor antidepressant. Then, he resumed therapy with St. John's wort, against medical advice. The name of the used preparation and its dosage was imprecise. As a result, he afterward developed a manic episode [31]. The discussion of the etiological factors that led to the occurrence of manic episodes in this patient can be conducted in different directions. On the one hand, it is known that SSRI antidepressants in small doses in unipolar disorder can be a trigger for mania and hypomania [32]. On the other hand, studies have shown that Hypericum has been recognized as an inhibitor of the monoamine oxidase A (MAO-A) and MAO-B in mitochondrial extracts of rat brain [33]. Another interesting report is the described case of mania in a patient with unilateral cryptorchidism. More importantly, in this patient are found elevated LH (luteinizing hormone) level, while testosterone level was within the normal range. The mechanism for elevated $\mathrm{LH}$ was probably as a result of reduced feedback on the hypothalamic-pituitary axis [34]. Furthermore, a case of hypericum-induced mania in a patient with depression without concomitant use of other drugs and without a history of mania or hypomania has also been reported.

St. John's wort may be one of the principal precipitation factors of mania, hypomania, or increased cycling of mood conditions, especially in patients with occult bipolar disorder [35]. In general, the fact that the dose of the plant taken is unknown or greater than the recommended dose for the occurrence and course of the reported manic episode is vital. Due 
to the link between fibromyalgia and bipolar disorder, these findings should be the basis for understanding the pathophysiological processes for manic switching in patients with FM. The risk of a manic episode in FM should be properly assessed, estimated, and monitored.

\subsection{Hypericum extracts and providing analgesia.}

In vivo studies have shown the ability of low doses of the extract of $H$. perforatum ( $0.3 \%$ hypericin; $3-5 \%$ hyperforin) in modulating the pain threshold, thus providing analgesia in acute and chronic pain conditions. Moreover, this improves its activity as an opioid [36]. As for acute pain, the dry extracts of $H$. perforatum given orally have been shown to increase the pain threshold in chemical and thermal pain in mice [37]. The activity of this plant related to pain has also been shown in humans. Dry extracts used in the form of ear drops reduce pain in children with otitis media [38]. On the other hand, managing chronic pain is a common medical issue. Treatment of myalgia, lacerated or injured nerves, with dry extracts of this plant is wellknown since ancient times [39]. A number of studies have also shown an effect of improving neuropathic pain. According to some clinical studies (implemented both in traditional and conventional medical frameworks) is also used for pain after tooth extraction, as well as for dental pain [39]. Analgesia occurs at low doses and, at the same time, minimizes the risk of herbal-drug interactions produced by hyperforin, a powerful inducer of Cytochromes P450 enzymes (CYPs) and the manic switch in people with concurrent bipolar disorders [40]. Further on, enzyme assays made on rat brains proved that hypericin and pseudohypericin are selective and potent inhibitors of the enzyme protein kinase $\mathrm{C}$ (PKC). PKC belongs to the group of enzymes that play a role in various cellular responses, including modulation of the pain threshold [41]. As well, it should be pointed out that St. John's wort has been used as adjuvant therapy with morphine in the treatment of chronic neuropathic pain [40]. Table 1 summarizes the effects of Hypericum extracts in different acute and chronic pain conditions.

\subsection{General features of Hypericum scruglii.}

Recently, $H$. scruglii have been identified as shikimic and chlorogenic acids, quercitrin, hyperoside, hypericin, and two phloroglucinol derivatives. Although discovered in small quantities, it is still significant due to its chemotaxonomic role [42]. It should be noted the $\alpha-$ glucosidase and antioxidant inhibitory activity of this species. Usually, it can be found in the pools. Overall, H. scruglii is associated with calcareous substrates such as conglomerate, limestone, sandstone, travertine, and marl, where it develops simply on damp soil, near springs or streams with fresh water. On top of that, H. scruglii is disseminated in the southeast and central-east parts of the island of Sardinia, especially in the Barbagia of Seulo, Sarcidano, Quirra, and Ogliastra regions [43]. According to one study, H. scruglii, was characterized by high quercitrin, 3-geranyl-1-(2'-methylbutanoyl)-phloroglucinol and 3-geranyl-1-(2'methylpropanoyl)-phloroglucinol content. In addition, $H$. scruglii showed the highest antioxidant and anti- $\alpha$-glucosidase activity than $H$. perforatum. These traits make $H$. scruglii an advantageous target in fibromyalgia studies [42]. Due to specific possessing characteristics makes this species as a potential carrier in the fight against the pathogenetic mechanisms of fibromyalgia and short turns that lead to relapses [18].

We can conclude the following: 1) The analgesic (anti-pain) effect can be the best solution for most disabling symptoms reported by the patients; 2) The antidepressant effect can improve the basic mood, part of the "catastrophic" cognitive cascade, which occurs as a 
consequence of hypersensitivity to pain that paradoxically grows the possibility of chronicity [18]; 3) The specific antioxidant effect can take part in the establishment of a balance between glutamate and GABA neurotransmitters; 4) The serotoninergic effect can modulate sleep.

3.5. Accessibility of new approaches for developing the oral bioavailability of very poor watersoluble molecules of the extracts of Hypericum.

Oral delivery of drugs is considered as the most appropriate route to reach therapeutic and prophylactic outcome against different diseases, especially chronic conditions, such as FM [45]. Bioavailability is investigated to be one of the crucial effects associated with the pharmacokinetics of drugs.

It consists of two important components, how fast the drug presents the systemic circulation and how much of the formal strength come to circulation [46]. Poor bioavailability indicates the non-success of the drug to reach the minimal productive concentration in the blood to turn-out the wanted therapeutic effects. To overcome these issues, new approaches are created. Not long ago, nanomedicines have achieved attention for growing the bioavailability of drugs in their dosage forms, mostly poorly water-soluble drugs [47].

Table 1. A therapeutic perspective of Hypericum extracts for pain conditions.

\begin{tabular}{|c|c|c|c|c|c|}
\hline Title of publication & $\begin{array}{l}\text { Authors, } \\
\text { year }\end{array}$ & $\begin{array}{l}\text { Character } \\
\text { of the pain }\end{array}$ & Type of pain & Animal/Patient & Consequence/Effect \\
\hline $\begin{array}{l}\text { Anti-inflammatory } \\
\text { and analgesic } \\
\text { activity of Indian } \\
\text { Hypericum } \\
\text { perforatum L. [27] }\end{array}$ & $\begin{array}{l}\text { Kumar et } \\
\text { al., } \\
(2001)\end{array}$ & Acute & Thermal & Mouse & Thermal antinociception \\
\hline $\begin{array}{l}\text { Anti-inflammatory } \\
\text { and analgesic } \\
\text { activity of Indian } \\
\text { Hypericum } \\
\text { perforatum L. [27] }\end{array}$ & $\begin{array}{l}\text { Kumar et } \\
\text { al. } \\
(2001)\end{array}$ & Acute & Chemical & Mouse & $\begin{array}{l}\text { Chemical } \\
\text { antinociception }\end{array}$ \\
\hline $\begin{array}{l}\text { Efficacy of } \\
\text { naturopathic } \\
\text { extracts in the } \\
\text { management of ear } \\
\text { pain associated with } \\
\text { acute otitis media } \\
{[44]}\end{array}$ & $\begin{array}{l}\text { Sarrell } \\
\text { al. } \\
(2001)\end{array}$ & Acute & Acute otitis media & Children & $\begin{array}{l}\text { Advancement in ear pain } \\
\text { score }\end{array}$ \\
\hline $\begin{array}{l}\text { John's Wort relieves } \\
\text { neuropathic pain } \\
\text { through a hypericin- } \\
\text { mediated inhibition } \\
\text { of the protein kinase } \\
\text { C gamma and } \\
\text { epsilon activity [51] }\end{array}$ & $\begin{array}{l}\text { Galeotti } \\
\text { et al. } \\
(2010)\end{array}$ & Chronic & $\begin{array}{l}\text { Chronic } \\
\text { constriction injury }\end{array}$ & Rat & $\begin{array}{l}\text { Rebuilding of thermal } \\
\text { and mechanical } \\
\text { hyperalgesia }\end{array}$ \\
\hline $\begin{array}{l}\text { The effect of } \\
\text { Hypericum } \\
\text { perforatum on the } \\
\text { wound healing and } \\
\text { scar of } \\
\text { cesarean [52] }\end{array}$ & $\begin{array}{l}\text { Samadi } e t \\
\text { al. } \\
(2010)\end{array}$ & Acute & Surgical childbirth & Women & Mitigation of the pain \\
\hline $\begin{array}{l}\text { An experience with } \\
\text { paediatric burn } \\
\text { wounds treated with } \\
\text { a plant-derived } \\
\text { wound therapeutic } \\
\text { [53] }\end{array}$ & $\begin{array}{l}\text { Mainetti } \\
\text { S, } \\
\text { Carnevali } \\
\text { F. } \\
(2013)\end{array}$ & Acute & Burn wounds & Children & $\begin{array}{l}\text { Mitigation of the pain } \\
\text { [62] }\end{array}$ \\
\hline $\begin{array}{l}\text { St. John's Wort } \\
\text { potentiates } \\
\text { antinociceptive } \\
\text { effects of morphine } \\
\text { in mice models of }\end{array}$ & $\begin{array}{l}\begin{array}{l}\text { Sanna } \\
\text { al. }\end{array} \\
\text { (2016) }\end{array}$ & Chronic & $\begin{array}{l}\text { Antiretroviral- } \\
\text { induced } \\
\text { neuropathy }\end{array}$ & Mouse & $\begin{array}{l}\text { Rebuilding of thermal } \\
\text { and mechanical } \\
\text { hyperalgesia }\end{array}$ \\
\hline \multicolumn{6}{|c|}{ https://biointerfaceresearch.com/ } \\
\hline
\end{tabular}




\begin{tabular}{|c|c|c|c|c|c|}
\hline Title of publication & $\begin{array}{l}\text { Authors, } \\
\text { year }\end{array}$ & $\begin{array}{l}\text { Character } \\
\text { of the pain }\end{array}$ & Type of pain & Animal/Patient & Consequence/Effect \\
\hline \multicolumn{6}{|l|}{$\begin{array}{l}\text { neuropathic pain } \\
\text { [54] }\end{array}$} \\
\hline $\begin{array}{l}\text { Hypericum } \\
\text { perforatum (St. } \\
\text { John's Wort) as a } \\
\text { possible therapeutic } \\
\text { alternative for the } \\
\text { management of } \\
\text { trigeminal } \\
\text { neuralgia (TN)-A } \\
\text { case report [55] }\end{array}$ & $\begin{array}{l}\begin{array}{l}\text { Assiri } \quad \text { et } \\
\text { al. }\end{array} \\
(2017)\end{array}$ & Chronic & $\begin{array}{l}\text { Trigeminal } \\
\text { neuralgia }\end{array}$ & Patients & Reduction of the pain \\
\hline
\end{tabular}

Nanonization as an approach is very important because it improves the solubility and pharmacokinetics of drugs, and on the other hand, reduces systemic side effects [48]. In the middle of the different nanocarriers, modified liposomes have shown a good capacity simultaneously to increase the local and systemic efficacy of natural molecules or extract [49, 50]. These formulations may boost the oral bioavailability of very poor water-soluble molecules such as hypericin, hyperforin, quercetin, and rutin, which are available in the hypericum extracts. In a previous study, cyclodextrin and liposomal preparations were investigated for improving the transportation of hypericin through the intestinal epithelium by passive transcellular diffusion. The successful removal of bioactive phytocomplex from $H$. scruglii and its satisfactory nanoformulation in ad hoc modified liposomes should upgrade the efficacy of the extract in preventing FM symptoms and the accordance of patients in reducing the dose and the number of compulsory administrations.

\section{Conclusions}

In vivo and in vitro, animal studies show that it is possible to improve the therapeutic properties of $H$. scruglii. All this is due to the fact that this species shows better results in preliminary clinical studies on fibromyalgia compared to other species of the family Hypericaceae. The authors appraise that in phase 1 and phase 2 studies should be prepared randomized controlled trials to evaluate the efficacy of $H$. scruglii extracts in fibromyalgia. The need for this type of study is inevitable due to the fact that fibromyalgia and its consequences are major public health problems, for which to date, there are few effective therapies, and they import a greater risk of the manic switch.

\section{Funding}

This research received no external funding.

\section{Acknowledgments}

Goce Kalcev (MD) was participating in the writing of this paper, in the framework of the International $\mathrm{PhD}$ in Innovation Sciences and Technologies at the University of Cagliari, Italy.

\section{Conflicts of Interest}

The authors declare no conflict of interest. 


\section{References}

1. Conversano, C.; Marchi, L.; Rebecca, C.; Carmassi, C.; Contena, B.; Bazzichii L.M.; Gemignani A. Personality Traits in Fibromyalgia (FM): Does FM Personality Exists? A Systematic Review. Clin Pract Epidemiol Ment Health 2018, 14, 223-232, https://doi.org/10.2174/1745017901814010223.

2. Carta, M.G.; Moro, M.F.; Pinna, F.L.; Testa, G.; Cacace, E.; Ruggiero, V.; Piras, M.; Romano, F.; Minerba, L.; Machado, S.; Freire, R.C.; Nardi, A.E.; Sancassiani, F. The impact of fibromyalgia syndrome and the role of comorbidity with mood and post-traumatic stress disorder in worsening the quality of life. Int $J$ Soc Psychiatry 2018, 64, 647-655, https://doi.org/10.1177/0020764018795211.

3. Hudson, J.I.; Hudson, M.S.; Pliner, L.F.; Goldenberg, D.L.; Pope, H.G. Fibromyalgia and major affective disorder: a controlled phenomenology and family history study. Am J Psychiatry 1985, 142, 441-446, https://doi.org/10.1176/ajp.142.4.441.

4. Naliboff, B.D.; Derbyshire, S.W.; Munakata, J.; Berman, S.; Mandelkern, M.; Chang, L.; Mayer, E.A. Cerebral activation in patients with irritable bowel syndrome and control subjects during rectosigmoid stimulation. Psychosom Med 2001, 63, 365-375, https://doi.org/10.1097/00006842-200105000-00006.

5. Giesecke, T.; Gracely, R.H.; Grant, M.A.; Nachemson, A.; Petzke,F.; Williams, D.A.; Clauw, D.J.; Evidence of augmented central pain processing in idiopathic chronic low back pain. Arthritis Rheum 2004, 50, 613620, https://doi.org/10.1002/art.20063.

6. Ozgocmen, S.; Ozyurt, H.; Sogut, S.; Akyo, 1. O.; Ardicoglu, O.; Yildizhan, H. Antioxidant status, lipid peroxidation and nitric oxide in fibromyalgia: etiologic and therapeutic concerns. Rheumatol Int 2006, 26, 598-603, https://doi.org/10.1007/s00296-005-0079-y.

7. Cordero, M.D.; De Miguel, M.; Moreno Fernández, A.M.; Carmona López, I.M.; Garrido Maraver, J.; Cotán, D.; Lourdes Gómez, I.; Bonal, P.; Campa, F.; Bullon, P.; Navas, P.; José A Sánchez, A. Affiliations expand Mitochondrial dysfunction and mitophagy activation in blood mononuclear cells of fibromyalgia patients: implications in the pathogenesis of the disease. Arthritis Res Ther 2010, 12, https://doi.org/10.1186/ar2918.

8. Yoshimura, M.; Furue, H. Mechanisms for the antinociceptive actions of the descending noradrenergic and serotonergic systems in the spinal cord. Journal of Pharmacological Sciences 2006, 101, 107-117, https://doi.org/10.1254/jphs.crj06008x.

9. Herman, J.P.; Figueiredo, H.F.; Mueller, N.K.; Ostrander, M.M.; Zhang, R.; Tauchi, M.; Choi, D.C.; Furay, A.R.; Evanson, N.K.; Nelson, E.B.; Ulrich-Lai, Y.M. Neurochemical Systems Regulating the HypothalamoPituitary-Adrenocortical Axis. In: Handbook of Neurochemistry and Molecular Neurobiology: Behavioral Neurochemistry, Neuroendocrinology and Molecular Neurobiology. Lajtha, A., Blaustein, J.D. Eds. Springer US: Boston, MA, 2007; https://doi.org/10.1007/978-0-387-30405-2_13.

10. Suzuki, R.; Rygh, L.J.; Dickenson, A.H. Bad news from the brain: descending 5-HT pathways that control spinal pain processing. Trends in Pharmacological Sciences 2004, 25, 613-617, https://doi.org/10.1016/j.tips.2004.10.002.

11. McCarley, R.W.; Neurobiology of REM and NREM sleep. Sleep Medicine 2007, 8, 302-330, https://doi.org/10.1016/j.sleep.2007.03.005.

12. Cano, A.; Corley, A.M.; Clark, S.M.; Martinez, S.C. A couple-based psychological treatment for chronic pain and relationship distress. Cognit. Behav. Pract 2018, 25, 119-134, https://doi.org/10.1016/j.cbpra.2017.02.003.

13. Albrecht, D.S.; Forsberg, A.; Sandström, A.; Bergan, C.; Kadetoff, D.; Protsenko, E.; Lampa, J.; Lee, Y.C.; Höglund, C.O.; Catana, C.; Cervenka, S.; Akeju, O.; Lekander, M.; Cohen, G.; Halldin, C.; Taylor, N.; Kim, M.; Hooker, J.M.; Edwards, R.R.; Napadow, V.; Kosek, E.; Loggia, M.L. Brain glial activation in fibromyalgia - A multi-site positron emission tomography investigation. Brain, Behavior, and Immunity 2019, 75, 72-83, https://doi.org/10.1016/j.bbi.2018.09.018.

14. Pereira, V.; Goudet, C. Emerging trends in pain modulation by metabotropic glutamate receptors. Frontiers in Molecular Neuroscience 2019, 11, 1-22, https://doi.org/10.3389/fnmol.2018.00464.

15. Enna, S.J.; McCarson, E.K. The role of gaba in the mediation and perception of pain. Advances in Pharmacology 2006, 54, 1-27, https://doi.org/10.1016/s1054-3589(06)54001-3.

16. Rus, A.; Molina, F.; Ramos, M.M.; Martínez-Ramírez, M.J.; Del Mora, L. Extra Virgin Olive Oil Improves Oxidative Stress, Functional Capacity, and Health-Related Psychological Status in Patients With Fibromyalgia: A Preliminary Study. Biol Res Nurs 2017, 19, 106-115, https://doi.org/10.1177/1099800416659370.

17. Baggiani, G.; Ambrosiani, L.; Trincas, P.; Burrai, C.; Bocchetta, A. Psychotropic Medication of Acute Episodes of Mood Disorders: Current Prescription Attitude in Two Psychiatric Wards in Cagliari, Italy. Clinical Practice \& Epidemiology in Mental Health 2018, 14, 236-249, https://doi.org/10.2174/1745017901814010236.

18. Tzadok, R.; Ablin, J.N. Current and Emerging Pharmacotherapy for Fibromyalgia. Pain Res Manag 2020, 2020, 1-9, https://doi.org/10.1155/2020/6541798.

19. Freeman, M.P. Complementary and alternative medicine (CAM): considerations for the treatment of major depressive disorder. J. Clin. Psychiatry 2009, 70 , 4-6, https://doi.org/10.4088/JCP.8157su1c.01. 
20. Hypericum Depression Trial Study Group. Effect of Hypericum perforatum (St John's wort) in major depressive disorder: a randomized controlled trial. JAMA 2002, 287, 1807-1814, https://doi.org/10.1001/jama.287.14.1807.

21. Zirak, N.; Shafiee, M.; Soltani, G.; Mirzaei, M.; Sahebkar, A. Hypericum perforatum in the treatment of psychiatric and neurodegenerative disorders: Current evidence and potential mechanisms of action. J Cell Physiol 2018, 234, 8496-8508, https://doi.org/10.1002/jcp.27781.

22. Ng, O.; Venkatanarayanan, N.; Ho, C. Clinical use of Hypericum perforatum (St John's wort) in depression: A meta-analysis. J Affect Disord 2017, 210, 211-221, https://doi.org/10.1016/j.jad.2016.12.048.

23. Singer, A.; Wonnemann, M.; Müller, W.E. Hyperforin, a major antidepressant constituent of St. John's wort, inhibits serotonin uptake by elevating free intracellular Na+. J. Pharmacol. Exp. Ther 1999, 290, 1363-1368.

24. Markowitz, J.S.; Donovan, J.L.; DeVane, C.L.; Taylor, R.M.; Ruan, Y.; Wang, J.S.; Chavin, K.D. Effect of St John's wort on drug metabolism by induction of cytochrome P450 3A4 enzyme. JAMA 2003, 290, 15001504, https://doi.org/10.1001/jama.290.11.1500.

25. Silva, B.A.; Ferreres, F.; Malva, G.O.; Dias, A.C.P. Phytochemical and antioxidant characterization of Hypericum perforatum alcoholic extracts. Food Chemistry 2005, 90, 157-167, https://doi.org/10.1016/j.foodchem.2004.03.049.

26. Wang, H.; Zhang, W.; Gao, Q.; Cao, X.; Li, Y.; Li, X.; Min, Z.; Yu, Y.; Guo, Y.; Shuai, L. Extractive from Hypericum ascyron L promotes serotonergic neuronal differentiation in vitro. Stem Cell Res 2018, 31, 4250, https://doi.org/10.1016/j.scr.2018.07.003.

27. Kumar, V.; Singh, P.N.; Bhattacharya, S.K. Anti-inflammatory and analgesic activity of Indian Hypericum perforatum L. Indian J. Exp. Biol 2001, 39, 339-343.

28. Bostock, E.; Kirkby, K.; Garry, M.; Taylor, B.; Hawrelak, J.A. Mania Associated With Herbal Medicines, Other Than Cannabis: A Systematic Review and Quality Assessment of Case Reports. Front Psychiatry 2018, 9, https://doi.org/10.3389/fpsyt.2018.00280.

29. Craddock, N.; Sklar, P. Genetics of bipolar disorder. Lancet 2013, 38, 1654-62, https://doi.org/10.1016/S0140-6736(13)60855-7.

30. Barbuti, M.; Pacchiarotti, I.; Vieta, E.; Azorin, J.M.; Angst, J.; Bowden, C.L. Antidepressant-induced hypomania/mania in patients with major depression: evidence from the BRIDGE-II-MIX study. $J$ Affect. Disord 2017, 219, 187-192, https://doi.org/10.1016/j.jad.2017.05.035.

31. Barbenel, D.M.; Yusufi, B.; O’Shea, D.; Bench, C.J. Mania in a patient receiving testosterone replacement postorchidectomy taking St John's wort and sertraline. J Psychopharmacol 2000, 14, 84-86, https://doi.org/10.1177/026988110001400113.

32. Spigset, O. Adverse reactions of selective serotonin reuptake inhibitors: reports from a spontaneous reporting system. Drug Safety 1999, 20, 277-287, https://doi.org/10.2165/00002018-199920030-00007.

33. Hyttel, J. Comparative pharmacology of selective serotonin reuptake inhibitors (SSRIs). Nord J Psychiatry 1993, 47, 5-20, https://doi.org/10.3109/08039489309104119.

34. Whalley, L.; Christie, J.; Bennie, J.; Dick, H.; Sloan-Murphy, J.; Fink, G. Elevated plasma luteinizing hormone concentration, cryptotchidism and mania. Psychoneuroendocrinology 1987, 12, 73-77, https://doi.org/10.1016/0306-4530(87)90025-4.

35. Fahmi, M.; Huang, C.; Schweitzer, I. A case of mania Induced by Hypericum. The World Journal of Biological Psychiatry 2002, 3, 58-59, https://doi.org/10.3109/15622970209150602.

36. Galeotti, N. Hypericum perforatum (St John's wort) beyond depression: A therapeutic perspective for pain conditions. J Ethnopharmacol 2017, 200, 136-146, https://doi.org/10.1016/j.jep.2017.02.016.

37. Kumar, S.; Pandey, A.K. Chemistry and biological activities of flavonoids: an overview. Scientific World Journal 2013, 2013, 1-16, https://doi.org/10.1155/2013/162750.

38. Sarrell, E.M.; Mandelberg, A.; Cohen, H.A. Efficacy of naturopathic extracts in the management of ear pain associated with acute otitis media. Arch Pediat rAdolesc Med 2001, 155, 796-799, https://doi.org/10.1001/archpedi.155.7.796.

39. Fernie, W.T. Herbal Simples: approved for Modern Uses of Cure. 1997, https://doi.org/10.1016/C2013-007765-1.

40. Sanna, M.D.; Ghelardin, C.; Galeotti, N. St. John's Wort Potentiates anti-Nociceptive Effects of Morphine in Mice Models of Neuropathic Pain. Pain Med 2017, 18, 1334-1343, https://doi.org/10.1093/pm/pnw241.

41. Takahashi, I.; Nakanishi, S.; Kobayashi, E.; Nakano, H.; Suzuki, K.; Tamaoki, T. Hypericin and pseudohypericin specifically inhibit protein kinase C: Possible relation to their antiretroviral activity. Biochem Biophys Res Commun 1989, 165, 1207-1212, https://doi.org/10.1016/0006-291x(89)92730-7.

42. Mandrone, M.; Scognamiglio, M.; Fiorentino, A.; Sanna, C.; Cornioli, L.; Antognoni, F.; Bonvicini, F.; Polia, F. Phytochemical profile and $\alpha$-glucosidase inhibitory activity of Sardinian Hypericum scruglii and Hypericum hircinum. Fitoterapia 2017, 120, 184-193, https://doi.org/10.1016/j.fitote.2017.06.020.

43. Bacchetta, G.; Brullo, S.; Salmeri, C. Hypericum scruglii sp. nov. (Guttiferae) from Sardinia. Nordic Journal of Botany 2010, 28, 469-474, https://doi.org/10.1111/j.1756-1051.2009.00736.x.

44. Sarrell, E.M.; Mandelberg, A.; Cohen, H.A. Efficacy of naturopathic extracts in the management of ear pain associated with acute otitis media. Arch. Pediatr Adolesc Med 2001, 155, 796-799. https://doi.org/10.1001/archpedi.155.7.796. 
45. Lavelle, E.C.; Sharif, S.; Thomas, N.W.; Holand, J.; Davis, S.S. The importance of gastrointestinal uptake of particles in the design of oral delivery systems. Adv Drug Deliv Rev 1995, 18, 5-22, https://doi.org/10.1016/0169-409X(95)00048-C.

46. Thakkar, H.; Patel, B.; Thakkar, S. A review on techniques for oral bioavailability enhancement of drugs. Int J Pharm Sci Rev Res 2010, 4, 203-223.

47. Chen, H.; Khemtong, C.; Yang, X.; Chang, X.; Gao, J. Nanonization strategies for poorly water-soluble drugs. Drug Discov Today 2011, 16, 354-360, https://doi.org/10.1016/j.drudis.2010.02.009.

48. Riehemann, K.; Schneider, S.W.; Luger, T.A.; Godin, B.; Ferrari, M.; Fuchs, H. Nanomedicine-challenge and perspectives. Angew Chem Int Ed Engl 2009, 48, 872-897, https://doi.org/10.1002/anie.200802585.

49. Catalán-Latorre, A.; Pleguezuelos-Villa, M.; Castangia, I.; Manca, M.L.; Caddeo, C.; Nácher, A.; DíezSales, O.; Esteban-Peris, J.; Pons, R.; Escribano-Ferrer, E.; Fadda, A.M.; Manconi, M. Nutriosomes: prebiotic delivery systems combining phospholipids, a soluble dextrin and curcumin to counteract intestinal oxidative stress and inflammation. Nanoscale 2018, 10, 1957-1969, https://doi.org/10.1039/c7nr05929a.

50. Manconi, M.; Marongiu, F.; Castangia, I.; Manca, M.L.; Caddeo, C.; Tuberoso, G.; D’hallewin, G.; Bacchetta, G.; Fadda, A.M. Polymer-associated liposomes for the oral delivery of grape pomace extract. Colloids Surf B-Biointerfaces 2016, 146, 910-917, https://doi.org/10.1016/j.colsurfb.2016.07.043.

51. Galeotti, N.; Vivoli, E.; Bilia, A.R.; Bergonzi, M.C.; Bartolini, A.; Ghelardini, C. A prolonged Protein Kinase C-mediated, opioid-related antinociceptive effect of St John's Wort in mice. J. Pain 2010, 11, 149159, https://doi.org/10.1016/j.jpain.2009.06.013.

52. Samadi, S.; Khadivzadeh, T.; Emami, A.; Moosavi, N.S.; Tafaghodi, M.; Behnam, H.R. The effect of Hypericum perforatum on the wound healing and scar of cesarean. J. Altern Complement Med 2010, 16, 113-117, https://doi.org/10.1089/acm.2009.0317.

53. Mainetti, S.; Carnevali, F. An experience with paediatric burn wounds treated with a plant-derived wound therapeutic. J Wound Care 2013, 22, 681-682, https://doi.org/10.12968/jowc.2013.22.12.681.

54. Sanna, M.D.; Ghelardini, C.; Galeotti, N. St. John's Wort potentiates antinociceptive effects of morphine in mice models of neuropathic pain. Pain Med 2016, 18, 1-10, https://doi.org/10.1093/pm/pnw241.

55. Assiri, K.; Alyami, Y.; Uyanik, J.M.; Romero-Reyes, M. Hypericum perforatum (St. John's Wort) as a possible therapeutic alternative for the management of trigeminal neuralgia (TN)-A case report. Complement Ther Med 2017, 30, 36-39, https://doi.org/10.1016/j.ctim.2016.10.014.

56. Kelly, G.A.; Blake, C.; Power, C.K.; O’Keeffe, D.; Fullen, B.M. The association between chronic low back pain and sleep: a systematic review. Clin J Pain 2011, 27, 169-181, https://doi.org/10.1097/AJP.0b013e3181f3bdd5.

57. Rouhi, S.; Dadkhah, P.; Firoozi, M.; Hashemi, M. New Model for Couple Therapy for Patients with Chronic Pain and their Caregivers: An Attempt to Improve Quality of Life and Reduce Pain. Clinical Practice \& Epidemiology in Mental Health 2020, 16, 53-58, https://doi.org/10.2174/1745017902016010053.

58. Sancassiani, F.; Carmassi, C.; Romano, F.; Balestrieri, M.; Caraci, F.; Sciascio, G, Drago, F.; Faravelli, C.; Hardoy, M.C.; Moro, M.F.; Roncone, R.; Preti, A.; Dell'Osso, L. Impairment of Quality of Life Associated With Lifetime Diagnosis of Post-traumatic Stress Disorder in Women-A National Survey in Italy. Clinical Practice \& Epidemiology in Mental Health 2019, 15, 38-43, https://doi.org/10.2174/1745017901915010038.

59. Nardi, A.E.; Karam, E.G.; Carta, M.G. Fibromyalgia patients should always be screened for post-traumatic stress disorder. Expert Rev Neurother 2020, https://doi.org/10.1080/14737175.2020.1794824.

60. Preti, A.; Stocchino, S.; Pinna, F.; Deidda, M.C.; Musu, M.; Sancassiani, F.; Romano, F.; Machado, S.; Finco, G.; Carta, M.G. BEEP-Bodily and Emotional Perception of Pain. A Questionnaire to Measure Reaction to Pain in Chronic Pain Disorders. Front Psychol 2019, 10, https://doi.org/10.3389/fpsyg.2019.00480.

61. Conversano, C.; Carmassi, C.; Bertelloni, C.A.; Marchi, L.; Micheloni, T.; Carbone, M.G.; Pagni, G.; Tagliarini, C.; Massimetti, G.; Bazzichi, L.M.; Dell’Osso, L. Potentially traumatic events, PTSD and posttraumatic stress spectrum in patients with fibromyalgia. Clin. Exp. Rheumatol 2018, 116, 39-43.

62. Seyhan, N. Evaluation of the Healing Effects of Hypericum perforatum and Curcumin on Burn Wounds in Rats. Evid Based Complement Alternat Med 2020, 2020, 1-5, https://doi.org/10.1155/2020/6462956.

63. Finsterer, F.; Stollberger, C. How Do Depressive Mood or Antidepressants Acutely Increase Serum Catecholamines? Clinical Practice \& Epidemiology in Mental Health 2019, 15, 1-2, https://doi.org/10.2174/1745017901915010001.

64. Di Tella, M.; Tesio, V.; Ghiggia, A.; Romeo, A.; Colonna, F.; Fusaro, E.; Geminiani, G.C.; Bruzzone, M.; Torta, R.; Castelli, L. Coping strategies and perceived social support in fibromyalgia syndrome: Relationship with alexithymia. Scand. J. Psychol 2018, 59, 167-176, https://doi.org/10.1111/sjop.12405.

65. Sancassiani, F.; Preti, A.; Cacace, E.; Ruggiero, V.; Testa, G.; Romano, F.; Carta, M.G. Alexithymia and sense of coherence: Does their impact on fibromyalgia suggest new targets for therapy? Gen Hosp Psychiatry 2019, 59, 78-79, https://doi.org/10.1016/j.genhosppsych.2018.12.001.

66. Sancassiani, F.; Machado, S.; Ruggiero, V.; Cacace, E.; Carmassi, C.; Gesi, C.; Dell' Osso, L.; Carta, M.G. The management of fibromyalgia from a psychosomatic perspective: an overview. Int Rev Psychiatry 2017, 29, 473-488, https://doi.org/10.1080/09540261.2017.1320982. 
67. Mameli, S.; Pisanu, G.M.; Sardo, S.; Marchi, A.; Pili, A.; Carboni, M.; Minerba, L.; Trincas, G.; Carta, M.G.; Melis, M.R.; Agabio, R. Oxytocin nasal spray in fibromyalgic patients. Rheumatol Int 2014, 34, 1047-1052, https://doi.org/10.1007/s00296-014-2953-y.

68. Carta, M.; Ruggiero, V.; Sancassiani, F.; Cutrano, F.; Manca, A.; Peri, M.; Fais, A.; Cacace, E. The Use of Antidepressants in the Long-Term Treatment Should not Improve the Impact of Fibromyalgia on Quality of Life. Clin Pract Epidemiol Ment Health 2013, 9, 120-124, https://doi.org/10.2174/1745017901309010120.

69. Carta, M.G.; Cardia, C.; Mannu, F.; Intilla, G.; Hardoy, M.C.; Anedda, C.; Ruggero, V.; Fornasier, D.; Cacace, E. The high frequency of manic symptoms in fibromyalgia does influence the choice of treatment? Clin Pract Epidemiol Ment Health 2006, 19, https://doi.org/10.1186/1745-0179-2-36. 